\title{
Life Writing "from Below" in Europe: Introduction
}

\author{
T. G. Ashplant
}

King's College London

In Shakespeare's comedy Love's Labour's Lost (1590s), Sir Nathaniel (a curate) says of Dull (a constable):

Sir, he hath never fed of the dainties that are bred in a book; he hath not eat paper, as it were; he hath not drunk ink: his intellect is not replenished; he is only an animal, only sensible in the duller parts: And such barren plants are set before us, that we thankful should be, which we of taste and feeling are, for those parts that do fructify in us more than he.

(Love's Labour's Lost, IV.ii.24-27)

This complacent view long prevailed, that the common people were incapable of producing autobiographical writing which fitted the classic definition by Roy Pascal: "the best autobiographies are by men and women of outstanding achievement in life" who experience "a consistent relationship, a sort of harmony, between outward experience and inward growth or unfolding, between incidents and the spiritual digestion of them." This notion, that there is but one single valuable form of life writing, came under illuminating feminist critique in the 1970s as regards texts written by women; and similar arguments are pertinent to the understanding and valuing of other forms of life writing by authors outside (predominantly male) elites. Within this perspective, a wide range of forms of text comes into consideration.

The term life writing "from below" is intended to be broad (accommodating) in a double sense: as regards the social status of authors, but also the genre of writing. The phrase "from below" draws on an analogy with the now well-established formulation "history from below" (Sharpe; Hitchcock). In the first instance it refers to authors from low down in a class or status hierarchy. Depending on the society and period in focus, such 
authors may be slaves, serfs, peasants, crofters, landless labourers, artisans, industrial workers ... and may be referred to as-or may designate themselves-plebeians, the labouring poor, the common people, the popular classes, artisans, proletarians, the working class. For the early modern period, James Amelang explains his choice of the term "popular autobiography":

\begin{abstract}
'Popular' evokes a category of social classification commonly used during the period. The 'people' (pueblo, popolo, menu peuple, Volk, and the like) were those commoners who occupied a middling rank between the elites above them and the marginal classes below, which include beggars, the unemployed and transients of all sorts. The economic, political and cultural resources at their command varied greatly. Their life experience could range from poverty, alienation from political life (both institutional and informal) and illiteracy, to a substantial degree of material comfort, limited but effective participation in local politics and extensive use of the skills of reading and writing. (32)
\end{abstract}

For the period of industrialisation, I follow the approach of John Burnett, David Vincent, and David Mayall in their bibliography of British workingclass autobiography:

Our aim was to include those who for some period of their lives could be described as working class, whether defined in terms of their relationship with the means of production, their educational experiences and cultural ties, by self-ascription, or by any combination of these factors. ${ }^{2}$

To varying degrees within diverse social structures, authors might change social position over their lifetime: either through upward social mobility, or (perhaps more commonly) by moving (back and forth) across the sometimes fluid social boundary between working class and lower/lesser middle class. Such transitions could clearly affect their perception and evaluation of their social circumstances. ${ }^{3}$

By using a different spatial metaphor, "on the margins," one could extend this category to include other social groups who-for reasons including gender, race, ethnicity, nationality, religion, sexuality-have had little or no access to the necessary resources (including formal education), and the established cultural forms within their own society, for recording their story, for making their voices heard. It is also crucial to recognise what has come to be understood as intersectionality: that gender, race and other such social markers can create multiple and overlapping forms of marginalisation, so that not all life writing from below comes from the same position, or the same degree or mode, of exclusion. ${ }^{4}$ 
The abstract project of attempting "history from below" can only be realised through the writing of multiple histories from below, which will necessarily be different and sometimes contradictory. In a similar fashion, the capacious category of "life writing from below" brings together texts in many genres produced by a wide range of social groups. Just as Jacques Presser's concept of "ego-document," which has been widely used to indicate a broad category of life writings, can best be understood in terms of what the philosopher Ludwig Wittgenstein dubbed a "family resemblance," where there is no single essential feature common to all, but rather a group of similarities which overlap; so too the term "life writing from below" does not seek to designate a tightly-bounded field. The texts it comprises may differ in origin, form or purpose. ${ }^{5}$ Nevertheless, in addition to their shared articulation of perspectives which would otherwise remain unknown, there are evident within this family of texts certain commonalities and continuities-such as genre, oral/written cross-over, problems of patronage and access to publication-which make it valuable to explore them together. ${ }^{6}$

Over the past forty years, life writings from below have attracted growing attention, both within and outside the academy. Several diverse factors have played a part. Since the late 1960s, the development of social, and more recently cultural, history as distinct fields has encouraged a search for sources through which to explore the experiences and mentalités of non-elite social groups. The retreat from class politics, and decline in the organisations and dominant narratives of the traditional labour movements (socialist and communist parties, trade unions), have prompted exploration of the world views of workers with different (or no such) institutional or ideological affiliations. Efforts at social reconciliation and cultural reconstruction, after the wars and civil wars which have scarred most European societies in the twentieth century, have included the assembling of archives of autobiographies, diaries and letters of those caught up in conflict, whether as engaged participants or conscripts. Local political initiatives, often bringing together committed scholars and activists with ordinary citizens, have generated autobiographical publishing projects addressing specific local audiences.

Many life writings from below expressed a demand for justice, a recognition of the value and dignity not just of the individual author, but also of the community from which they came, and on whose behalf they also sought to speak. Today, too, such texts are produced and circulated to challenge demeaning narratives about, and representations of, groups on the margins of society, such as recipients of state welfare. Most recently, human rights organisations have gathered refugee narratives in an effort to assist the acceptance and integration within Europe of those fleeing conflicts in Africa, the Middle East and elsewhere. 
Exploration of the collection, archiving, and interpretation of such life writing in various European countries suggests that there is a considerable body of such archival and scholarly practices, but that it remains in some ways quite segmented: divided by barriers of nation, language, academic discipline, and scholarly subject, as well as between the academy and the wider world. Consequently, though there have been several significant collaborative research projects, there is still less intellectual cross-fertilisation than there might be. ${ }^{7}$

This cluster of articles in the European Journal of Life Writing is the product of the project "Life Writing from Below in Europe: Comparative Perspectives," based at the Centre for Life-Writing Research (CLWR), King's College London, whose aim is to bring together researchers across Europe who share an interest in, and engagement with, life writing from below. ${ }^{8}$ The purpose of the cluster is to highlight the wide range of forms of life writing from below, and the national and disciplinary diversity of approaches to their archiving and interpretation, in order to encourage further collaborative and comparative scholarship.

T. G. Ashplant's article offers an overview of the diverse forms of life writing from below in Europe since the early modern period; the traditions of collecting and archiving which have developed since the midtwentieth century; and some of the major interpretative themes which have explored these texts. This mapping, of both texts and scholarship, aims to highlight the connections as well as divergences within this body of texts, and to indicate the potentials for cross-fertilisation in archival practice, scholarly research and social engagement.

The next three articles analyse specific national traditions, from the late sixteenth century to the present day. Fabian Brändle analyses the rich history of Swiss popular writing, built on high social mobility, relatively early successful literacy, and Protestant self-introspection. As in many other European countries, this tradition includes autodidact artisans and craftsmen. However, in contrast with Britain, France and Germany, many of these Swiss texts were written by people on the margins of society, rather than by members of a labour movement. Brändle also identifies specific local traditions (of religion, gender, class, and language/ dialect) which fostered such writing; and sketches the strengths and limitations of what has currently been achieved in the editing and collecting of Swiss popular autobiography. Anna Kuismin, in her discussion of texts produced in rural Finland in the nineteenth century, by people largely lacking any formal education, extends understanding of life writings from below to embrace texts carved on wooden boards, or woven into textiles. Working with whatever materials came to hand, and employing the skills used in their daily lives, these authors thereby found a creative 
medium to express their subjectivity. Nathalie Ponsard presents an overview of the changing ways in which French workers' autobiographies have been analysed by scholars. An initial focus on workers' political relationship to the dominant (especially Communist) institutions and ideologies of the labour movement was followed by attention to broader efforts to depict the impact of work processes and relationships of power within the factory, and then to a re-evaluation of the literary aims and ambitions of such workers' writings.

Two further articles concern very distinctive examples of life writing from below, which nevertheless exemplify themes (of motivation, sponsorship, publication, and preservation) that are evident much more widely. Arianne Baggerman and Rudolf Dekker examine religious autobiographies written by Dutch Pietists, a rather isolated religious group in the Dutch Bible Belt, living mostly in small villages. More than 200 were written and published, mainly between 1850 and 1950; together they form a large proportion of all Dutch ego-documents. More than a quarter of the authors were women (well above the average ratio of female life writers in the nineteenth century). Most of the authors came from a background of poverty, with little formal education. Though their focus is on religious life and conversion, many texts reveal much about the daily life and conditions of the Dutch poor. The publication history of these texts shows the importance of intermediaries-whether religious ministers, or commercial publishers exploiting a niche market-in translating what often began as spoken narratives for family, friends or congregation into written and then printed texts. Yet-like many other forms of life writing from belowfew of these autobiographies, which were often simply short, cheap booklets, were preserved in public or research libraries; only now are they being systematically collected.

Martyn Lyons, in reviewing a recent study of prison letters from the Spanish Civil War, highlights how this very specific corpus encapsulates many key aspects of life writings from below. Written from incarceration, and sometimes in the face of execution, some letters are extreme examples of state compulsion to tell one's story in the hope of mitigating one's fate. This required expressing oneself in the approved formulas of the Francoist regime. Others, sometimes smuggled out of prison, took on a double task: to re-establish and reaffirm connection with family and loved ones, while also vindicating one's life choices and political engagement. This combination of intimate personal with public goals locates these texts within one central purposive pattern of life writing from below. The collecting, editing, analysing and publishing of these letters, as part of the (belated) recovery of historical memory of the Civil War now under 
way in Spain, exemplifies the contribution which, through committed and sensitive scholarship, life writings from below can make to public discourse and the assertion of human rights.

\section{WORKS CITED}

Amelang, James S. "Vox Populi: Popular Autobiographies as Sources for Early Modern Urban History." Urban History 20.1 (1993): 30-42.

Ashplant, T. G. "Writing the Lives of the Poor." European Journal of Life Writing 3 (2014): R1-R6.

Boos, Florence. "Class and Victorian Poetics." Literature Compass 2 (winter), VI.115 (2005): $1-20$.

Boos, Florence. "Introduction: the Literature of the Victorian Working Classes." Philological Quarterly 92.2 (spring) (2013): 131-145.

Brah, Avtar, and Ann Phoenix. "Ain't I a Woman? Revisiting Intersectionality." Journal of International Women's Studies 5.3 (May) (2004): 75-86.

Burnett, John, David Vincent, and David Mayall, eds. The Autobiography of the Working Class: an Annotated Critical Bibliography, 3 vols. Brighton: Harvester, 1984-1989.

Coleman, Heather J. "Becoming a Russian Baptist: Conversion Narratives and Social Experience." Russian Review 61.1 (Jan.) (2002): 94-112.

Dekker, Rudolf. "Introduction." Ed. Dekker. Egodocuments and History: Autobiographical Writing in its Social Context Since the Middle Ages. Hilversum: Verloren, 2002. 7-20.

Gestrich, Andreas, Elizabeth Hurren, and Steven Kin, eds. Poverty and Sickness in Modern Europe: Narratives of the Sick Poor, 1780-1938. London: Continuum, 2012.

Hitchcock, Tim. "A New History from Below." History Workshop Journal 57 (spring) (2004): 294-298.

Jensen, Birgit A. "'What Wretched Creatures Are We Servants!': Female Working-Class Agency in Two German Autobiographies at the Turn of the Century." Auto/Biography Studies 20.1 (2005): 59-75.

Kuismin, Anna. "From Family Inscriptions to Autobiographical Novels: Motives for Writing in Grassroots Life Stories in 19th-Century Finland.” Eds. Kuismin and Driscoll. 2013. 101-119.

Kuismin, Anna, and M. J. Driscoll, eds. White Field, Black Seeds: Nordic Literacy Practices in the Long Nineteenth Century. Helsinki: Finnish Literature Society, 2013.

Liljewall, Britt. "Recollections of Reading and Writing: Another Picture of Swedish Literacy." Eds. Kuismin and Driscoll, 2013. 30-39.

Lorenzen-Schmidt, Klaus-Joachim, and Bjørn Poulsen, eds. Writing Peasants: Studies on Peasant Literacy in Early Modern Northern Europe. [n.p.]: Landbohistorisk Selskab, 2002.

Lundin, Johan A. "The Salvation Army in Sweden and the Making of Gender: Conversion Narratives 1887-1918." Journal of Religious History 37.2 (Jun.) (2013): 245-260.

Lutz, Helma, Maria Teresa Herrera Vivar, and Linda Supik, eds. Framing Intersectionality: Debates on a Multi-Faceted Concept in Gender Studies. Farnham: Ashgate, 2011.

Lyons, Martyn. The Writing Culture of Ordinary People in Europe, c.1860-1920. Cambridge: Cambridge University Press, 2012.

Moss, David. "Introduction: Special Issue on Terra Matta." Journal of Modern Italian Studies 19.3 (Jun.) (2014): 223-240.

Pascal, Roy. Design and Truth in Autobiography. London: Routledge and Kegan Paul, 1961.

Paul dans sa Vie. Dir. Rémi Mauger, 103 mins, France, 2005. 
Sharpe, Jim. "History from Below." Ed. Peter Burke. New Perspectives on Historical Writing. Cambridge: Polity Press, 1991. 24-41.

Sokoll, Thomas, ed. Essex Pauper Letters, 1731-1837. Oxford: Oxford University Press/British Academy, 2001.

Stanley, Liz. The Auto/biographical I: the Theory and Practice of Feminist Auto/biography. Manchester: Manchester University Press, 1992.

Wittgenstein, Ludwig. Philosophical Investigations. 2nd ed. Oxford: Blackwell, 1967.

\section{ABOUT THE AUTHOR}

T. G. Ashplant is a Visiting Professor at the Centre for Life-Writing Research, King's College London. He is a social and cultural historian, with a research interest in life writings as a source for exploring the construction and transformation of class and gender subjectivities, and their relationship to political identities. He has recently published "Life Writings from Below in Europe," History Workshop Journal no. 79 (spring 2015), 274-289; and has co-edited (with AnnCatrine Edlund and Anna Kuismin) Reading and Writing from Below: Exploring the Margins of Modernity (2016). He is author of Fractured Loyalties: Masculinity, Class and Politics in Britain, 1900-30 (London: RiversOram, 2007); and co-editor of Explorations in Cultural History (with Gerry Smyth; London: Pluto Press, 2001).

\section{NOTES}

1 Pascal, 10. Jensen, 59, comments: "Texts produced by authors of the lower classes have long been omitted from the literary canons in general, and working-class autobiographies in particular have customarily been dismissed as uninteresting and nonaesthetic. This latter bias, however, might stem from the unarticulated assumption that the proper autobiographical narrator is an autonomous middle-class individual (usually male) who reveals the formation of a centered and unified self in the creative act of writing." Cf. Stanley, 11-13.

2 Burnett et al., Vol. 1, xxi. Boos 2013, 132-3, follows this definition, adding: "The writers discussed in the following essays [a special issue on Nineteenth-Century Working-Class Writing] were in most cases manual laborers and/or the children of manual laborers, and a major aspect of their deprivation was the difficulty with which they obtained access to education." Issues of definition and terminology in relation to authorship of life writings are also discussed by Liljewall, 31; Kuismin, 104; Coleman, 97 and n.12 on Baptist converts in Russia ("the majority of converts to the Baptist faith in the early twentieth century were lower or lower-middle class, including peasants, workers, artisans, petty traders, and domestics."); Lundin 2013a, 248 (most applicants to become Salvation Army officers in Sweden, 1887-1918, "came from working-class backgrounds. ... the men worked in a factory or in the forests, and there were some ex-military individuals of lower rank. The women were mainly ex-factory workers, servants and, occasionally, preschool teachers.)"; Moss, 230, 238 n.9 (“diversamente colti"); Lyons, 13-14, 17-18 ("ordinary writings").

3 Boos 2005, 11, makes this point in relation to several significant nineteenth-century British women authors: "How, moreover, should one interpret class-boundaries in the 
cases of Mary Smith, Eliza Cook, Ethel Carnie, and others who lived at different times on one or another side of the elusive divides between lower, lower-middle, and middle class?"

4 "We regard the concept of 'intersectionality' as signifying the complex, irreducible, varied, and variable effects which ensue when multiple ax $[\mathrm{e}] \mathrm{s}$ of differentiation-economic, political, cultural, psychic, subjective and experiential-intersect in historically specific contexts. The concept emphasizes that different dimensions of social life cannot be separated out into discrete and pure strands." Brah and Phoenix, 75; cf. Lutz et al., 1-22.

5 Wittgenstein, §64-71. Dekker, 7, notes that Presser introduced ego-document as "a generic and neutral term to cover this broad variety of textual forms (diaries, memoirs, personal letters, other forms of autobiographical writing)". Presser used it for "all texts in which an author wrote about his or her own feelings, thoughts or actions"; and later more broadly as "those documents in which an ego intentionally or unintentionally discloses, or hides itself".

6 The documentary film Paul dans sa Vie (dir. Rémi Mauger, France, 2005), about the life of Paul Bedel, born 1930, a traditional farmer from Auderville (Normandy), reveals one such continuity. It shows the livres de raison (recording weather, sales, prices) which he had kept throughout his working life-a genre dating back at least to the early modern period and often cited as one of the origins of autobiography_as well as a later form of his self-writing: notebooks of religious reflections. My thanks to Pol de Jong for introducing me to this film.

7 An early example of such comparative work is the informal network of scholars in northern Europe working on "peasant diaries," which between 1983 and 2005 held (and published proceedings of) four conferences; see the last of these: Lorenzen-Schmidt and Poulsen (eds); and for a final report on the "Internationale Assoziation zur Erforschung bäuerlicher Schreibebücher," http://hsozkult.geschichte.hu-berlin.de/projekte/id=119. Thomas Sokoll's pioneering work on pauper letters helped to inspire an Anglo-German research project, "Pauper Letters and Petitions for Poor Relief in Germany and Great Britain, 1770-1914," to construct an online, edited corpus of such texts, which survive in considerable numbers in British and German archives. The strategies of these letters were examined comparatively in Gestrich et al. (eds); and they were placed in their wider textual context at the conference "Writing the Lives of the Poor" (German Historical Institute, London, November 2013; see Ashplant). Another important initiative to cross such national and disciplinary boundaries has been made in the Nordic countries, within the framework of the history of "literacy" broadly defined, as the whole range of practices involved in the production, dissemination and reception of written texts. An initial Academy of Finland project: 'The common people', Writing, and the Process of Literary Attainment in the 19th Century Finland (2008-2011) stimulated the creation of the transnational network Reading and Writing From Below: Toward a New Social History of Literacy in the Nordic Sphere During the Long Nineteenth Century (2011-2014), funded by the Joint Committee for Nordic Research Councils for the Humanities and the Social Sciences (see http://blogs.helsinki.fi/nord-corp/, and the resultant papers in Kusimin \& Driscoll (eds).) Also relevant, though not limited to texts from below, is the project "Self-Narratives in Transcultural Perspective," Research Group 530 of the German Research Foundation (DFG) (http://www.firstpersonwritings.eu/germany/ germany_project.htm). National research networks have also been formed. There is a strong tradition in Italy of the study of "scrittura popolare" (with its roots in labour and local history). Both L'Archivio della scrittura popolare, based at the Historical Museum in Trento, and L'Archivio ligure della scrittura popolare, based at the University of Genoa, have edited, and published widely on, working-class and "popular" writing. Together, they helped to form the Federazione degli archivi della scrittura popolare, in 1989. This held 
a series of annual seminars till 1993, and has produced a book series Fiori secchi. Testi e studi di scrittura popolare (Dried Flowers. Texts and Studies of Popular Writing), which includes, as introduction to the published texts or separately, socio-historical, linguistic, and anthropological studies dedicated to the social practice of writing. In Spain, the Seminar Interdisciplinar por los Estudios sobre la Cultura Escrita, at the University of Alcalá de Henares (Madrid), has organised a series of conferences on this theme, resulting in several edited books. It also published the biannual journal, Cultura Escrita and Sociedad (2005-2010), with a particular (though not exclusive) focus on the writing of the subaltern/popular classes; and hosts La Red de Archivos e Investigadores de la Escritura Popular which links relevant Spanish archives. Life writings from below in France are included in the CNRS-supported project "Les écrits du for privé en France de la fin du Moyen Age à 1914" (2003-2010; http://ecritsduforprive.huma-num.fr/); while Swiss scholars have produced a combined database from three research projects on life-writings (http://wp.unil.ch/egodocuments).

8 The participants are grateful to Professors Clare Brant and Max Saunders, Co-directors of CLWR, for their support for this project.

See http://www.kcl.ac.uk/artshums/ahri/centres/lifewriting/Research/Life-Writingfrom-Below.aspx.

The articles below by Anna Kuismin and Nathalie Ponsard are revised versions of papers presented to a seminar at CLWR in June 2014. 